\title{
Moderate tetrabasic zinc chloride supplementation improves growth performance and reduces diarrhea incidence in weaned pigs
}

\author{
Gang Zhang ${ }^{1}$, Tian Xia”, Jinbiao Zhao ${ }^{1}$, Ling Liu', Pingli He ${ }^{1}$, Shuai Zhang ${ }^{1, *}$, and Liying Zhang ${ }^{1, *}$
}

\author{
* Corresponding Authors: \\ Shuai Zhang \\ Tel: +86-010-62731109, Fax: +86-010-62733688, \\ E-mail: zhangshuai16@cau.edu.cn \\ Liying Zhang \\ Tel: +86-6273-1272, Fax: +86-6273-3700, \\ E-mail: zhangliying01@sina.com \\ 'State Key Laboratory of Animal Nutrition, China \\ Agricultural University, Beijing 100193, China \\ ORCID \\ Gang Zhang \\ https://orcid.org/0000-0001-8732-9279 \\ Tian Xia \\ https://orcid.org/0000-0001-8251-6294 \\ Jinbiao Zhao \\ https://orcid.org/0000-0001-7900-0131 \\ Ling Liu \\ https://orcid.org/0000-0002-0761-5185 \\ Pingli He \\ https://orcid.org/0000-0002-7462-1382 \\ Shuai Zhang \\ https://orcid.org/0000-0001-5435-2640 \\ Liying Zhang \\ https://orcid.org/0000-0003-3991-5075
}

Submitted Dec 2, 2018; Revised Jan 24, 2019; Accepted Apr 15, 2019
Objective: Two experiments were conducted to evaluate tetrabasic zinc chloride (TBZC) on the health of weaned pigs, and to determine the optimal supplemental concentrations and whether dietary TBZC could replace the pharmacological concentrations of dietary zinc oxide $(\mathrm{ZnO})$ to improve growth performance and decrease $\mathrm{Zn}$ excretion in weaned pigs.

Methods: In Exp. 1, 180 weaned pigs $(8.92 \pm 1.05 \mathrm{~kg}$ body weight [BW]) were randomly assigned to 1 of 5 treatments, including the basal diet containing $125 \mathrm{mg} / \mathrm{kg}$ zinc sulfate $\left(\mathrm{ZnSO}_{4}\right)$, and the basal diet with 1,200, 1,800, 2,400, or 3,000 mg/kg TBZC supplementation. In Exp. 2, 240 weaned pigs ( $7.66 \pm 1.09 \mathrm{~kg} \mathrm{BW})$ were randomly assigned to 1 of 5 treatments, including a negative control diet without $\mathrm{Zn}$ supplementation, a positive control diet $(2,250$ $\mathrm{mg} / \mathrm{kg} \mathrm{ZnO}$ ), and 3 experimental diets with different concentrations of TBZC supplementation $(1,000,1,250$, and $1,500 \mathrm{mg} / \mathrm{kg})$.

Results: In Exp. 1, the average daily gain (ADG), feed efficiency (G:F) and diarrhea incidence responded quadratically $(\mathrm{p}<0.01)$ as the TBZC supplemental concentrations increased, and pigs fed 1,200 and 1,800 mg/kg TBZC showed the best growth performance. Moreover, 1,800 $\mathrm{mg} / \mathrm{kg}$ TBZC supplementation showed the greatest $(\mathrm{p}<0.01)$ total antioxidant capacity and glutathione peroxidase activities in liver of pigs. Histopathological examination revealed lesions in heart, liver, lung and kidney, and mild or severe histological lesions mainly occurred with the supplementation of 2,400 and 3,000 mg/kg TBZC. In Exp. 2, 1,000 and 1,250 mg/kg TBZC supplementation in diets significantly $(\mathrm{p}<0.01)$ increased ADG and G:F of weaned pigs, reduced $\mathrm{Zn}$ excretion in feces, and had no effect on diarrhea-reducing compared to $2,250 \mathrm{mg} / \mathrm{kg} \mathrm{ZnO}$ supplementation.

Conclusion: The TBZC is a potential alternative to $\mathrm{ZnO}$. The recommended concentration of TBZC in weaned pig diets is 1,000 to $1,250 \mathrm{mg} / \mathrm{kg}$.

Keywords: Growth Performance; Weaned Pigs; Tetrabasic Zinc Chloride; Zinc Excretion

\section{INTRODUCTION}

Post-weaning diarrhea is one of the most common causes of morbidity and mortality for weaning pigs, and hence greatly impairs their growth performance [1]. Many studies and practical experiences have shown that inclusion of pharmacological doses of zinc oxide $(\mathrm{ZnO})$ in weaned pig diets can improve growth performance and decrease diarrhea incidence [2,3]. However, feeding high concentrations of $\mathrm{ZnO}$ (more than 2,250 mg/kg) to weaned pigs can result in environmental concerns due to excess zinc $(\mathrm{Zn})$ excretion in the manure. Excess accumulation of $\mathrm{Zn}$ in soil could deteriorate the soil quality, produce toxicity to plants, and potentially impair the health of animals and humans [3-5]. The influence of Zn excretion on the environment is long-lasting, therefore, it is suggested to formulate lower 
concentrations of $\mathrm{Zn}$ in animal diets and supplement $\mathrm{Zn}$ with high bioavailability to decrease the its excretion in weaned pigs.

Tetrabasic zinc chloride (TBZC) is an inorganic form of Zn produced by crystallization and has less heavy metal contamination than other $\mathrm{Zn}$ sources such as zinc sulfate $\left(\mathrm{ZnSO}_{4}\right)$ and $\mathrm{ZnO}$. Diet supplemented with TBZC has low oxidation risk during storage due to the low hygroscopic capacity of TBZC [6]. It is reported that the relative $\mathrm{Zn}$ bioavailability in TBZC is one to two times higher than that of feed-graded $\mathrm{ZnO}[6,7]$. As a result, the TBZC is an effective growth promoter requiring a lower dose concentration than that of $\mathrm{ZnO}$ and with less fecal $\mathrm{Zn}$ excreted into the environment. Furthermore, the TBZC has shown a stronger anti-diarrhea effect at a lower $\mathrm{Zn}$ dose compared to $\mathrm{ZnO}$ used in pharmacological doses in weaned pig diets, which is due to its better ability to reduce intestinal permeability and prevent the disruption of barrier integrity [1]. Therefore, TBZC would be a good source of inorganic $\mathrm{Zn}$ supplemented in weaned pig diets.

Previous research has shown that growth performance was no longer improved if the supplemental TBZC concentration was greater than $1,500 \mathrm{mg} / \mathrm{kg}$ in nursery pigs [7]. Hill et al [2] reported that this turning point for growth performance was $2,000 \mathrm{mg} / \mathrm{kg}$ for dietary $\mathrm{ZnO}$ supplementation in weaned pigs. Moreover, Swinkels et al [8] found that high concentrations of dietary Zn significantly increased pancreas and liver weights of pigs. The proteomic analysis also revealed that high concentrations of dietary $\mathrm{Zn}$ triggered many oxidative stress reactions in pancreases of young pigs [9]. All these results suggested that high concentration of dietary $\mathrm{Zn}$ is harmful to pig health and offsets its partial growth-promoting effect. However, few studies have focused on the feed safety, the appropriate dosage range and the $\mathrm{Zn}$ excretion of dietary TBZC supplementation in weaned pigs.

Therefore, the objectives of this study were i) to evaluate the effects of different concentrations of dietary supplemental TBZC on growth performance, organ morphology, hematological and serum biochemical characteristics in weaned pigs, then to determine dose-dependent effects of TBZC on response variables, and ii) to test whether replacing pharmacological concentrations of dietary $\mathrm{ZnO}$ with TBZC would further improve growth performance and decrease $\mathrm{Zn}$ excretion in weaned pigs.

\section{MATERIALS AND METHODS}

All procedures used in this study were conducted in accordance with the Chinese Guidelines for Animal Welfare and approved by the China Agricultural University Institutional Animal Care and Use Committee (Beijing, China). Two experiments were conducted using 420 crossbred (Durocx Landrace $\times$ Yorkshire) weaned pigs raised at the China Agriculture University Animal Experimental Base (Fengning,
China). In both experiments, pigs were housed in $1.2 \times 2.1 \mathrm{~m}^{2}$ pens equipped with plastic slatted floors, automatic stainless steel nipple drinkers, and feeders. Initial room temperature was maintained at $28^{\circ} \mathrm{C}$ and then decreased by $1^{\circ} \mathrm{C}$ weekly, and the relative humidity was controlled at $60 \%$ to $70 \%$. All pigs had ad libitum access to water and feed throughout the experiment. The $\mathrm{ZnO}$ containing $75 \% \mathrm{Zn}$ was a common feed-graded source and provided by Beijing Tonglixingke Company (Beijing, China), and the TBZC $\left[\mathrm{Zn}_{5}(\mathrm{OH})_{8} \mathrm{Cl}_{2} \cdot \mathrm{H}_{2} \mathrm{O}\right]$ containing $55 \% \mathrm{Zn}$ was provided by Changsha Xingjia Biotechnology Company (Changsha, China).

\section{Animals, diets, and experimental design}

In Exp. 1, one hundred and eighty crossbred weaned pigs $(8.92 \pm 1.05 \mathrm{~kg}$ of body weight [BW] and $28 \pm 3 \mathrm{~d}$ of age) were randomly assigned to 5 dietary treatments in a completely randomized design for a 28 -d experiment. There were 6 pens per treatment with 6 pigs ( 3 barrows and 3 gilts) per pen. Five dietary treatments were formulated using a two-phase feeding program, with the basal diet (Table 1) containing $125 \mathrm{mg} / \mathrm{kg} \mathrm{Zn}$ (as-fed basis) as $\mathrm{ZnSO}_{4}$, or with $0,1,200,1,800$, 2,400, or 3,000 mg/kg Zn (as-fed basis) as TBZC. All diets were fed in mash form and were formulated to meet or exceed the nutrient requirements of 7 to 11 and 11 to $25 \mathrm{~kg}$ pigs recommended by NRC [10].

In Exp. 2, two hundred and forty crossbred weaned pigs $(7.66 \pm 1.09 \mathrm{~kg}$ of BW and $28 \pm 3 \mathrm{~d}$ of age) were randomly assigned to 5 dietary treatments in a completely randomized design for a 28-d experiment. Each treatment diet was fed to 8 replicated pens with 6 pigs ( 3 barrows and 3 gilts) per pen. The basal diets used in Exp. 2 (Table 1) were formulated to meet or exceed the nutrient requirement, except for $\mathrm{Zn}$, of 7 to 11 and 11 to $25 \mathrm{~kg}$ pigs recommended by NRC [10]. No supplemental $\mathrm{Zn}$ source was included in the basal diet other than the intrinsic $\mathrm{Zn}$ in the other ingredients. The 5 dietary treatments consisted of a negative control diet without $\mathrm{Zn}$ addition (NC), a positive control diet with $\mathrm{ZnO}$ supplementation ( $\mathrm{NC}+2,250 \mathrm{mg} / \mathrm{kg} \mathrm{Zn}$ as $\mathrm{ZnO})$, and 3 experimental diets supplemented with different concentrations of TBZC ( $\mathrm{NC}+1,000,1,250$, and 1,500 $\mathrm{mg} / \mathrm{kg} \mathrm{Zn}$ as TBZC).

\section{Sample collection}

In both experiments, BWs and feed consumption (on pen basis) were measured on $\mathrm{d} 0,14$, and 28 to calculate the average daily gain (ADG), average daily feed intake (ADFI), and feed efficiency (G:F).

Diarrhea rate was calculated as:

Diarrhea rate (\%)

$=$ (number of pigs with diarrhea $\times$ diarrhea days $)$

/(number of pigs $\times$ total observational days $) \times 100$. 
Table 1. Ingredients and chemical compositions of the basal diets used in Exp. 1 and 2 (as-fed basis)

\begin{tabular}{|c|c|c|c|c|}
\hline \multirow{2}{*}{ Items } & \multicolumn{2}{|c|}{ Exp. 1} & \multicolumn{2}{|c|}{ Exp. 2} \\
\hline & d 0 to 14 & d 14 to 28 & d 0 to 14 & d 14 to 28 \\
\hline \multicolumn{5}{|l|}{ Ingredient (\%) } \\
\hline Corn & 60.58 & 66.16 & 51.64 & 58.53 \\
\hline Soybean meal (44\% CP) & 10.00 & 17.00 & 16.85 & 13.40 \\
\hline Extruded soybean & - & - & 14.20 & 11.00 \\
\hline Soy protein concentrate & 9.00 & 5.60 & - & - \\
\hline Fish meal & 4.70 & 2.00 & 4.00 & 5.00 \\
\hline Whey power & 10.00 & 4.00 & 8.00 & 7.00 \\
\hline Soybean oil & 1.26 & 1.00 & 1.65 & 1.32 \\
\hline Dicalcium phosphate & 0.79 & 0.86 & 1.21 & 1.10 \\
\hline Sodium bicarbonate & 0.88 & 0.85 & - & - \\
\hline Limestone & 0.74 & 0.73 & 0.74 & 0.50 \\
\hline Salt & 0.30 & 0.30 & 0.30 & 0.50 \\
\hline L-Lys $\mathrm{HCl}$ & 0.60 & 0.50 & 0.46 & 0.40 \\
\hline L-Thr & 0.22 & 0.17 & 0.13 & 0.10 \\
\hline DL-Met & 0.23 & 0.17 & 0.12 & 0.15 \\
\hline Chromic oxide & - & - & - & 0.30 \\
\hline Choline chloride (40\% Choline) & 0.20 & 0.16 & 0.20 & 0.20 \\
\hline Vitamin-mineral premix ${ }^{11}$ & 0.50 & 0.50 & 0.50 & 0.50 \\
\hline Total & 100.00 & 100.00 & 100.00 & 100.00 \\
\hline \multicolumn{5}{|l|}{ Calculated composition (\%) } \\
\hline Digestible energy (kcal/kg) & 3,542 & 3,480 & 3,550 & 3,480 \\
\hline Crude protein & 20.50 & 19.00 & 20.50 & 18.90 \\
\hline $\mathrm{Ca}$ & 0.84 & 0.74 & 0.85 & 0.75 \\
\hline$P$ & 0.67 & 0.64 & 0.66 & 0.65 \\
\hline Available P & 0.47 & 0.44 & 0.46 & 0.44 \\
\hline \multicolumn{5}{|c|}{ Standardized ileal digestible amino acid (\%) } \\
\hline Lys & 1.42 & 1.30 & 1.41 & 1.30 \\
\hline Met & 0.41 & 0.40 & 0.41 & 0.40 \\
\hline Thr & 0.82 & 0.75 & 0.80 & 0.74 \\
\hline Trp & 0.22 & 0.21 & 0.22 & 0.21 \\
\hline
\end{tabular}

1) Vitamin and mineral premix provided the following per kilogram of diet: 12,000 IU vitamin A (vitamin A acetate), 2,500 IU vitamin D (vitamin $\left.D_{3}\right), 30$ IU vitamin $E$ (dl-a-tocopheryl acetate), $12 \mu \mathrm{g}$ vitamin $\mathrm{B}_{12}, 3 \mathrm{mg}$ vitamin $\mathrm{K}$ (menadione sodium bisulfate), $15 \mathrm{mg}$ d-pantothenic acid (calcium pantothenate), $40 \mathrm{mg}$ nicotinic acid, $30 \mathrm{mg}$ Mn (manganese oxide), $120 \mathrm{mg}$ Fe (ferrus sulfate), $150 \mathrm{mg}$ Cu (copper sulfate), $0.35 \mathrm{mg}$ I (ethylenediamine dihydroiodide), and $0.3 \mathrm{mg}$ Se (sodium selenite). In addition, vitamin and mineral premix used in Exp. 1 contained $125 \mathrm{mg}$ Zn (zinc sulfate), and the premix in Exp. 2 did not.

In Exp. 1, one pig with median BW from each pen was selected to collect blood samples via the anterior vena cava on d 28 after an overnight fasting. Two blood samples were collected for each pig: one into $10-\mathrm{mL}$ sodium-heparinized vacutainer tubes, and then immediately placed on ice to measure hematological parameters; another into $10-\mathrm{mL}$ vacutainer tubes without anticoagulant. Subsequently, serum from the second blood sample was separated by centrifuged (Heraeus Biofuge 22R Centrifuge, Hanau, Germany) at 3,000 $\times \mathrm{g}$ for 10 min at $4^{\circ} \mathrm{C}$ and stored at $-20^{\circ} \mathrm{C}$ until further analysis. Pigs selected for blood sample collection were euthanized in the morning on d 29. Heart, liver, spleen, lung, and kidney were quickly removed and washed thoroughly with normal saline to remove the residual blood and then weighed. The tissue samples from these organs were immediately fixed in 2.5\% (v/v) glutaraldehyde-polyoxymethylene solution for morpho- logical analysis. Tissues of heart, liver, kidney, and pancreas were sampled and stored at $-70^{\circ} \mathrm{C}$ for minerals analysis. Liver tissue from one lobe was sampled and immediately stored in liquid nitrogen for antioxidant parameter analysis.

In Exp. 2, approximately $200 \mathrm{~g}$ of fecal samples were collected from each pen for 3 days (from d 26 to 28) and were stored at $-20^{\circ} \mathrm{C}$. After thawing, the 3 days collection of fecal samples were pooled by pen and then dried at $65^{\circ} \mathrm{C}$ for $72 \mathrm{~h}$. All samples were ground to pass through a 1-mm screen ( 40 mesh) before analysis. Chromic oxide (0.3\%) was used as an indigestible indicator.

\section{Mineral analysis}

Feeds (Exp. 1 and Exp. 2), organs (Exp. 1) and fecal (Exp. 2) samples were wet-digested using nitric-perchloric acid (3:1) and then diluted with deionized distilled water for analyses 
of minerals. Concentrations of $\mathrm{Zn}$, copper $(\mathrm{Cu})$, and iron $(\mathrm{Fe})$ were analyzed using a Flame Atomic Absorption Spectrophotometry (Z-5000; Hitachi, Tokyo, Japan). The percentages of mineral absorption were determined using the indicator method.

The following equations were used to calculate the percentages of mineral absorption, average daily mineral intake and average daily fecal mineral content:

$\mathrm{PM}=1-(\mathrm{DC} \times \mathrm{FM}) /(\mathrm{FC} \times \mathrm{DM})$

Average daily mineral intake $=\mathrm{ADFI} \times \mathrm{DM}$

Average daily fecal mineral $=\mathrm{ADFI} \times \mathrm{DM} \times(1-\mathrm{PM})$

Where DC is the content of $\mathrm{Cr}_{2} \mathrm{O}_{3}$ in the diets, $\mathrm{FM}$ is the content of mineral in the feces, $\mathrm{FC}$ is the content of $\mathrm{Cr}_{2} \mathrm{O}_{3}$ in the feces, DM is the content of mineral in the diets, $\mathrm{ADFI}$ is the average daily feed intake (d 26 to 28 ; as-fed basis) and PM is the percentages of mineral absorption.

\section{Hematological parameters, serum biochemistry and liver antioxidant parameters}

For hematological analysis, levels of hemoglobin (HGB) and hematocrit (HCT), and platelet (PLT), total white blood cells (WBC) and red blood cells (RBC) counts in blood samples were determined using a full automated hematology analyzer (MindrayBC-2800, Shenzhen, China). The concentrations of aspartate aminotransferase (AST), alanine aminotransferase (ALT), total bilirubin (T-BIL), creatinine (CREA), alkaline phosphatase (ALP), glucose (GLU), total protein (TP), albumin (ALB) and urea nitrogen in serum (SUN) were measured by corresponding commercial kits (BioSino Bio-technology and Science Inc., Beijing, China) using an automatic biochemical analyzer (Hitachi 7020, Hitachi High-Technologies Corporation, Japan). Concentration of malondialdehyde (MDA), total antioxidant capacity (T-AOC) and superoxide dismutase (SOD) and glutathione peroxidase (GSH-Px) activities in liver were determined using the corresponding commercial assay kits (Nanjing Jiancheng Bioengineering Institute, Nanjing, China) followed the manufacturer's instructions.

\section{Organ indexes and histology}

Indexes (the ratio of the organ weight to BW) of heart, liver, spleen, lung, and kidney of piglets slaughtered were calculated. The histological analyses of heart, liver, spleen, lung, and kidney were measured according to the method provided by Kuang et al [11]. Changes in organic structure were visualized using a light microscope. All organ samples were also examined for histological evidence of abnormality by an experienced technician.

\section{Statistical analysis}

Data for both experiments were checked for normality and outliers using the UNIVERIATE procedure of SAS 9.4 (SAS Institute Inc., Cary, NC, USA). Data were then analyzed through one-way analysis of variance using the general linear model procedure of SAS. Pen served as the experimental unit for growth performance, diarrhea incidence, and mineral excretion data. Individual pig was considered as the experimental unit for other indexes. Treatment means were calculated using the LSMEANS statement and separated by the Student-Newman-Keuls test. In addition, coefficients for unequally spaced contrasts were generated by interactive matrix language procedure of SAS, then orthogonal polynomials contrasts were conducted using the CONTRAST statement to determine linear and quadratic effects of increasing dietary concentrations of supplemental TBZC. Moreover, CONTRAST statement was also used to compare the effects of the NC diet vs the $\mathrm{ZnO}$ diet, and the $\mathrm{ZnO}$ diet vs mean of TBZC treatments on growth performance and diarrhea incidence, and the effects of $1,000 \mathrm{mg} / \mathrm{kg}, 1,250 \mathrm{mg} / \mathrm{kg}$, or $1,500 \mathrm{mg} / \mathrm{kg}$ TBZC diet vs the $\mathrm{ZnO}$ diet on mineral absorption and excretion of weaned pigs in Exp. 2. Differences were declared significant at $\mathrm{p}<0.05$, while $0.05 \leq p<0.10$ was considered to indicate a trend in the data.

\section{RESULTS}

The mineral composition of diets from the laboratory analysis are presented in Tables 2 and 3 for Exp. 1 and 2, respectively. The results showed that the dietary $\mathrm{Zn}$ concentrations were close to the formulated values.

Growth performance and diarrhea incidence in Exp. 1 In Exp. 1, in phase 1 (d 0 to 14), weaned pigs fed diets containing TBZC showed greater ADG $(\mathrm{p}<0.05)$ than pigs fed the basal diet, and there was no further increase in ADG when dietary $\mathrm{Zn}$ concentration as TBZC increased from 1,200 to

Table 2. Analyzed mineral compositions of diets used in Exp. 1

\begin{tabular}{lccccc}
\hline \multirow{2}{*}{ Items } & \multicolumn{5}{c}{ TBZC (mg/kg Zn) } \\
\cline { 2 - 6 } & $\mathbf{0}$ & $\mathbf{1 , 2 0 0}$ & $\mathbf{1 , 8 0 0}$ & $\mathbf{2 , 4 0 0}$ & $\mathbf{3 , 0 0 0}$ \\
\hline Phase 1, d 0 to 14 & & & & & \\
Zn (mg/kg) & 142 & 1,340 & 1,942 & 2,539 & 3,144 \\
Cu (mg/kg) & 163 & 161 & 164 & 159 & 161 \\
Fe (mg/kg) & 312 & 323 & 318 & 318 & 319 \\
Phase 2, d 14 to 28 & & & & & \\
Zn (mg/kg) & 144 & 1,346 & 1,947 & 2,546 & 3,143 \\
Cu (mg/kg) & 159 & 160 & 158 & 160 & 159 \\
Fe (mg/kg) & 322 & 327 & 330 & 323 & 325 \\
\hline
\end{tabular}

Analysis conducted in duplicates, and the Zn concentration in the basal diet (no TBZC supplementation) was $125 \mathrm{mg} / \mathrm{kg}$ as zinc sulfate $\left(\mathrm{ZnSO}_{4}\right)$.

TBZC, tetrabasic zinc chloride; Zn, zinc; Cu, copper; Fe, iron. 
Table 3. Analyzed mineral compositions of diets used in Exp. 2

\begin{tabular}{|c|c|c|c|c|c|}
\hline \multirow{2}{*}{ Items } & \multicolumn{4}{|c|}{ TBZC (mg/kg Zn) } & \multirow{2}{*}{$\frac{\mathrm{ZnO}(\mathrm{mg} / \mathrm{kg} \mathrm{Zn})}{2,250}$} \\
\hline & 0 (NC) & 1,000 & 1,250 & 1,500 & \\
\hline \multicolumn{6}{|c|}{ Phase $1, \mathrm{~d} 0$ to 14} \\
\hline Zn (mg/kg) & 33 & 1,045 & 1,272 & 1,568 & 2,259 \\
\hline $\mathrm{Cu}(\mathrm{mg} / \mathrm{kg})$ & 177 & 179 & 173 & 171 & 175 \\
\hline $\mathrm{Fe}(\mathrm{mg} / \mathrm{kg})$ & 288 & 293 & 290 & 281 & 280 \\
\hline \multicolumn{6}{|c|}{ Phase $2, \mathrm{~d} 14$ to 28} \\
\hline Zn (mg/kg) & 29 & 1,072 & 1,315 & 1,580 & 2,149 \\
\hline $\mathrm{Cu}(\mathrm{mg} / \mathrm{kg})$ & 175 & 177 & 172 & 174 & 172 \\
\hline $\mathrm{Fe}(\mathrm{mg} / \mathrm{kg})$ & 298 & 294 & 295 & 285 & 277 \\
\hline
\end{tabular}

Analysis conducted in duplicates.

TBZC, tetrabasic zinc chloride; NC, negative control without Zn source supplementation; ZnO, positive control, NC+2,250 mg/kg Zn as Zn oxide (ZnO); Zn, zinc; Cu, copper; Fe, iron.

$3,000 \mathrm{mg} / \mathrm{kg}$ (Table 4). In phase 2 (d 14 to 28 ) and during the overall 28-day period, the ADG $(\mathrm{p}<0.01)$ and ADFI $(\mathrm{p}<0.05)$ of weaned pigs responded quadratically as the dietary TBZC concentration increased, with pigs fed $1,800 \mathrm{mg} / \mathrm{kg} \mathrm{Zn}$ as TBZC having the greatest ADG numerically. However, pigs fed 3,000 $\mathrm{mg} / \mathrm{kg} \mathrm{Zn}$ as TBZC did not perform differently compared with pigs fed the basal diet.

In either phase 1 or 2 or during the whole period, the G:F and diarrhea incidence responded quadratically $(\mathrm{p}<0.01)$ as the dietary TBZC concentration increased. The G:F reached numerically the greatest in pigs fed diet with $1,800 \mathrm{mg} / \mathrm{kg} \mathrm{Zn}$ as TBZC. In addition, pigs fed diets containing TBZC significantly reduced the diarrhea incidence $(\mathrm{p}<0.05)$ compared with pigs fed the basal diet.

\section{Hematological parameters in Exp. 1}

On $\mathrm{d} 28$, the HGB level $(\mathrm{p}<0.01)$ and HCT $(\mathrm{p}<0.05)$ increased linearly as TBZC supplemental concentration increased (Table 5). Weaned pigs fed $3,000 \mathrm{mg} / \mathrm{kg} \mathrm{Zn}$ as TBZC showed greater $\mathrm{RBC}$ count $(\mathrm{p}<0.01)$ than pigs fed the basal diet. However, no significant differences $(\mathrm{p}>0.05)$ of WBC and PLT among the treatment groups were observed.

\section{Serum biochemical and liver antioxidant parameters} in Exp. 1

The AST and TP concentrations in serum of weaned pigs on $\mathrm{d} 28$ changed quadratically ( $<<0.01$ and $\mathrm{p}=0.04$, respectively) as the incremental concentrations of TBZC supplemented in diets (Table 6). Dietary TBZC inclusion linearly increased $(p<0.01)$ ALT and ALP levels in serum, and weaned pigs fed

Table 4. Effects of dietary tetrabasic zinc chloride supplementation on growth performance and diarrhea incidence of weaned pigs in Exp. 1

\begin{tabular}{|c|c|c|c|c|c|c|c|c|c|}
\hline \multirow{2}{*}{ Items } & \multicolumn{5}{|c|}{ TBZC (mg/kg Zn) } & \multirow{2}{*}{ SEM } & \multicolumn{3}{|c|}{$p$-value } \\
\hline & 0 & 1,200 & 1,800 & 2,400 & 3,000 & & Treatment & Linear $^{1)}$ & Quadratic $^{2)}$ \\
\hline \multicolumn{10}{|l|}{ Phase $1, \mathrm{~d} 0$ to 14} \\
\hline$A D G(g)$ & $331^{b}$ & $368^{\mathrm{a}}$ & $367^{\mathrm{a}}$ & $364^{a}$ & $366^{\mathrm{a}}$ & 11.56 & 0.02 & 0.07 & 0.09 \\
\hline ADFI (g) & 527 & 560 & 546 & 559 & 555 & 13.33 & 0.16 & 0.06 & 0.23 \\
\hline $\mathrm{G}: \mathrm{F}$ & $0.63^{c}$ & $0.66^{\mathrm{ab}}$ & $0.67^{\mathrm{a}}$ & $0.65^{b}$ & $0.66^{\mathrm{ab}}$ & 0.01 & $<0.01$ & $<0.01$ & $<0.01$ \\
\hline Diarrhea incidence (\%) & $10.95^{\mathrm{a}}$ & $0.48^{b}$ & $0.71^{b}$ & $1.67^{b}$ & $0.95^{b}$ & 0.94 & $<0.01$ & $<0.01$ & $<0.01$ \\
\hline \multicolumn{10}{|l|}{ Phase 2 , d 14 to 28} \\
\hline ADG $(\mathrm{g})$ & $387^{b c}$ & $417^{\mathrm{ab}}$ & $438^{\mathrm{a}}$ & $426^{a b}$ & $375^{c}$ & 15.24 & $<0.01$ & 0.89 & $<0.01$ \\
\hline ADFI (g) & 654 & 689 & 691 & 690 & 659 & 15.54 & 0.28 & 0.58 & 0.04 \\
\hline $\mathrm{G}: \mathrm{F}$ & $0.59^{c}$ & $0.61^{b c}$ & $0.63^{\mathrm{a}}$ & $0.62^{\mathrm{ab}}$ & $0.57^{d}$ & 0.01 & $<0.01$ & 0.41 & $<0.01$ \\
\hline Diarrhea incidence (\%) & $6.91^{\mathrm{a}}$ & $0.71^{b}$ & $0.24^{b}$ & $0.48^{b}$ & $0.95^{b}$ & 0.76 & $<0.01$ & $<0.01$ & $<0.01$ \\
\hline \multicolumn{10}{|l|}{ Overall, d 0 to 28} \\
\hline ADG $(\mathrm{g})$ & $359^{b}$ & $393^{\mathrm{a}}$ & $403^{\mathrm{a}}$ & $395^{\mathrm{a}}$ & $370^{b}$ & 12.10 & $<0.01$ & 0.04 & $<0.01$ \\
\hline ADFI (g) & 591 & 625 & 618 & 625 & 606 & 13.47 & 0.08 & 0.17 & 0.02 \\
\hline $\mathrm{G}: \mathrm{F}$ & $0.61^{b}$ & $0.63^{\mathrm{ab}}$ & $0.65^{\mathrm{a}}$ & $0.63^{\mathrm{ab}}$ & $0.61^{b}$ & 0.01 & 0.04 & 0.37 & $<0.01$ \\
\hline Diarrhea incidence (\%) & $8.93^{\mathrm{a}}$ & $0.60^{b}$ & $0.48^{b}$ & $1.07^{b}$ & $0.95^{b}$ & 0.63 & $<0.01$ & 0.03 & $<0.01$ \\
\hline
\end{tabular}

Values are least square means ( $\mathrm{n}=6$ per treatment), and zinc $(\mathrm{Zn})$ concentration in the basal diet (no TBZC supplementation) was $125 \mathrm{mg} / \mathrm{kg}$ as zinc sulfate $\left(\mathrm{ZnSO} \mathrm{H}_{4}\right.$ ).

TBZC, tetrabasic zinc chloride; SEM, standard error of the mean; ADG, average daily gain; ADFI, average daily feed intake; G:F, feed efficiency.

1). 2) Linear and quadratic effects of increasing TBZC concentrations (0 to $3,000 \mathrm{mg} / \mathrm{kg} \mathrm{Zn).}$

a-d Least square means within a row with different superscripts differ $(p<0.05)$. 
Table 5. Effects of dietary tetrabasic zinc chloride supplementation on hematological parameters in weaned pigs in Exp. 1

\begin{tabular}{|c|c|c|c|c|c|c|c|c|c|}
\hline \multirow{2}{*}{ Items } & \multicolumn{5}{|c|}{ TBZC (g/kg Zn) } & \multirow{2}{*}{ SEM } & \multicolumn{3}{|c|}{$\mathrm{p}$-value } \\
\hline & 0 & 1,200 & 1,800 & 2,400 & 3,000 & & Treatment & Linear $^{1)}$ & Quadratic \\
\hline White blood cell $\left(\times 10^{9} / \mathrm{L}\right)$ & 25.70 & 25.42 & 21.98 & 24.40 & 26.23 & 1.86 & 0.53 & 0.90 & 0.24 \\
\hline Red blood cell (× $\left.10^{12} / \mathrm{L}\right)$ & $6.48^{b}$ & $6.34^{b}$ & $6.49^{b}$ & $6.80^{\mathrm{ab}}$ & $7.09^{\mathrm{a}}$ & 0.13 & $<0.01$ & $<0.01$ & 0.02 \\
\hline Hemoglobin (g/L) & 98.19 & 105.40 & 102.25 & 113.60 & 114.40 & 4.25 & 0.06 & $<0.01$ & 0.65 \\
\hline Hematocrit (\%) & 34.01 & 35.98 & 36.33 & 38.22 & 38.70 & 1.32 & 0.14 & 0.01 & 0.92 \\
\hline Platelet count $\left(\times 10^{9} / \mathrm{L}\right)$ & 206.75 & 228.80 & 201.50 & 228.00 & 221.00 & 14.55 & 0.58 & 0.51 & 0.86 \\
\hline
\end{tabular}

Values are least square means ( $n=6$ per treatment), and zinc $(\mathrm{Zn})$ concentration in the basal diet (no TBZC supplementation) was $125 \mathrm{mg} / \mathrm{kg}$ as zinc sulfate $\left(\mathrm{ZnSO}_{4}\right)$. TBZC, tetrabasic zinc chloride; SEM, standard error of the mean.

${ }^{1,2)}$ Linear and quadratic effects of increasing TBZC concentrations (0 to 3,000 mg/kg Zn).

$a, b$ Least square means within a row with different superscripts differ $(p<0.05)$.

Table 6. Effects of dietary tetrabasic zinc chloride supplementation on serum biochemical and liver antioxidant parameters in weaned pigs in Exp. 1

\begin{tabular}{|c|c|c|c|c|c|c|c|c|c|}
\hline \multirow{2}{*}{ Items } & \multicolumn{5}{|c|}{ TBZC (mg/kg Zn) } & \multirow{2}{*}{ SEM } & \multicolumn{3}{|c|}{ p-value } \\
\hline & 0 & 1,200 & 1,800 & 2,400 & 3,000 & & Treatment & Linear $^{1)}$ & Quadratic $^{2)}$ \\
\hline \multicolumn{10}{|c|}{ Serum biochemical parameters } \\
\hline AST (U/L) & $67.60^{a b}$ & $64.30^{\mathrm{ab}}$ & $53.90^{b}$ & $80.63^{\mathrm{a}}$ & $80.75^{\mathrm{a}}$ & 4.67 & $<0.01$ & 0.03 & $<0.01$ \\
\hline $\operatorname{ALT}(U / L)$ & $60.11^{b}$ & $71.20^{\mathrm{ab}}$ & $81.88^{\mathrm{ab}}$ & $94.55^{\mathrm{a}}$ & $91.37^{\mathrm{ab}}$ & 6.30 & 0.02 & $<0.01$ & 0.26 \\
\hline$A L P(U / L)$ & $376.6^{b}$ & $467.3^{\mathrm{ab}}$ & $556.9^{\mathrm{ab}}$ & $764.4^{\mathrm{a}}$ & $682.6^{\mathrm{ab}}$ & 83.37 & 0.03 & $<0.01$ & 0.99 \\
\hline $\mathrm{TP}(\mathrm{g} / \mathrm{L})$ & 60.01 & 63.42 & 65.26 & 62.50 & 57.56 & 1.73 & 0.19 & 0.47 & 0.04 \\
\hline \multicolumn{10}{|c|}{ Liver antioxidant parameters } \\
\hline MDA (nmol/mg) & $0.33^{\mathrm{bc}}$ & $0.34^{b}$ & $0.30^{c}$ & $0.30^{c}$ & $0.38^{\mathrm{a}}$ & 0.01 & $<0.01$ & 0.06 & $<0.01$ \\
\hline GSH-Px (U/mg) & $41.86^{b}$ & $42.27^{b}$ & $57.87^{\mathrm{a}}$ & $48.38^{b}$ & $25.00^{c}$ & 2.26 & $<0.01$ & 0.02 & $<0.01$ \\
\hline T-AOC (U/mg) & $0.64^{b}$ & $0.56^{\mathrm{b}}$ & $0.76^{\mathrm{a}}$ & $0.75^{\mathrm{a}}$ & $0.46^{c}$ & 0.03 & $<0.01$ & 0.13 & $<0.01$ \\
\hline SOD (U/mg) & 4.23 & 4.03 & 5.06 & 4.43 & 3.94 & 0.34 & 0.20 & 0.96 & 0.19 \\
\hline
\end{tabular}

Values are least square means ( $n=6$ per treatment), and zinc (Zn) concentration in the basal diet (no TBZC supplementation) was $125 \mathrm{mg} / \mathrm{kg}_{\text {as }}$ zinc sulfate $\left(\mathrm{ZnSO} \mathrm{H}_{4}\right.$ ).

TBZC, tetrabasic zinc chloride; SEM, standard error of the mean; AST, aspartate aminotransferase; ALT, alanine aminotransferase; ALP, alkaline phosphatase; TP, total protein;

MDA, malondialdehyde; GSH-Px, glutathione peroxidase; T-AOC, total antioxidant capacity; SOD, superoxide dismutase.

${ }^{11.2)}$ Linear and quadratic effects of increasing TBZC concentrations ( 0 to 3,000 mg/kg Zn).

a-c Least square means within a row with different superscripts differ $(p<0.05)$.

$2,400 \mathrm{mg} / \mathrm{kg} \mathrm{Zn}$ as TBZC had the greatest ALT and ALP concentrations numerically. Additionally, there were no significant differences on T-BIL, CREA, GLU, ALB, and SUN levels in serum among all the treatment groups (date not shown).

In liver, the GSH-Px and T-AOC activities quadratically increased $(\mathrm{p}<0.01)$ as the TBZC supplemental concentration increased, and pigs fed $1,800 \mathrm{mg} / \mathrm{kg} \mathrm{Zn}$ as TBZC had the greatest ( $\mathrm{p}<0.01$; Table 6) GSH-Px activities. Hepatic MDA content on $\mathrm{d} 28$ showed a quadratic pattern $(\mathrm{p}<0.01)$ as TBZC supplemental concentration increased. In addition, pigs fed 3,000 $\mathrm{mg} / \mathrm{kg} \mathrm{Zn}$ as TBZC showed the lowest GSH-Px and T-AOC activities, as well as the highest MDA content $(\mathrm{p}<0.01)$.

\section{Organ weight and organ $\mathrm{Zn}$ concentrations in Exp. 1}

Incremental increase in TBZC supplemental concentration linearly increased $(\mathrm{p}<0.05)$ liver weight, liver index and kidney index, and quadratically altered lung weight, kidney weight $(\mathrm{p}<0.05)$ and lung index $(\mathrm{p}<0.01)$ in weaned pigs on d 28 (Table 7). However, there were no significant effect of dietary TBZC supplementation on weights and indexes of heart and spleen in weaned pigs ( $\mathrm{p}>0.05)$.

On d 28, increment in TBZC supplemental concentration linearly increased $(\mathrm{p}<0.01) \mathrm{Zn}$ concentrations in heart, liver, kidney and pancreas (Table 8). The $\mathrm{Zn}$ concentrations of heart, liver and kidney in pigs fed diets containing 2,400 or 3,000 $\mathrm{mg} / \mathrm{kg} \mathrm{Zn}$ as TBZC were greater than those of pigs fed 1,200 $\mathrm{mg} / \mathrm{kg} \mathrm{Zn}$ as TBZC and the basal diets.

\section{Histopathological analysis of organs in Exp. 1}

Morphological changes of heart, liver, spleen, lung, and kidney with graded concentrations of TBZC supplementation are shown in pictures A1-A5, B1-B5, C1-C5, D1-D5, and E1-E5, respectively (Figure 1). Histopathological examination revealed dose-related lesions in heart, liver, lung and kidney, and mild or severe histological lesions mainly focused on treatments with 2,400 and 3,000 mg/kg Zn as TBZC. Briefly, interstitial edema was observed in heart (A5), hepatocytes swelled and lymphocytes infiltrated in liver (B5). Some alveolar collapsed and the alveolar space enlarged compensatory. In addition, visible protein mucus appeared in the alveolar 
Table 7. Effects of dietary tetrabasic zinc chloride supplementation on organ weight and visceral index in weaned pigs in Exp. 1

\begin{tabular}{|c|c|c|c|c|c|c|c|c|c|}
\hline \multirow{2}{*}{ Items } & \multicolumn{5}{|c|}{ TBZC (mg/kg Zn) } & \multirow{2}{*}{ SEM } & \multicolumn{3}{|c|}{$p$-value } \\
\hline & 0 & 1,200 & 1,800 & 2,400 & 3,000 & & Treatment & Linear $^{1)}$ & Quadratic $^{2)}$ \\
\hline \multicolumn{10}{|c|}{ Weight (g) } \\
\hline Heart & 104.40 & 100.79 & 101.84 & 90.85 & 98.44 & 5.84 & 0.56 & 0.25 & 0.85 \\
\hline Liver & 465.59 & 473.00 & 475.69 & 498.17 & 532.45 & 15.90 & 0.07 & 0.01 & 0.14 \\
\hline Spleen & 46.80 & 45.69 & 47.16 & 41.80 & 49.98 & 3.67 & 0.64 & 0.89 & 0.47 \\
\hline Lung & $225.33^{b}$ & $230.99^{b}$ & $286.27^{\mathrm{a}}$ & $252.19^{\mathrm{ab}}$ & $219.98^{b}$ & 12.25 & 0.01 & 0.56 & 0.01 \\
\hline Kidney & $94.56^{b}$ & $97.98^{b}$ & $102.47^{b}$ & $106.43^{b}$ & $121.60^{\mathrm{a}}$ & 3.77 & $<0.01$ & $<0.01$ & 0.05 \\
\hline \multicolumn{10}{|c|}{ Visceral index (g/kg) } \\
\hline Heart & 5.58 & 5.50 & 5.68 & 5.14 & 5.31 & 0.29 & 0.69 & 0.37 & 0.72 \\
\hline Liver & 25.91 & 26.00 & 26.86 & 27.72 & 29.29 & 0.85 & 0.08 & 0.01 & 0.18 \\
\hline Spleen & 2.40 & 2.50 & 2.66 & 2.38 & 2.73 & 0.18 & 0.60 & 0.35 & 0.93 \\
\hline Lung & $12.25^{b}$ & $13.25^{\mathrm{ab}}$ & $15.47^{\mathrm{a}}$ & $12.85^{\mathrm{ab}}$ & $11.82^{b}$ & 0.70 & 0.03 & 0.89 & $<0.01$ \\
\hline Kidney & $5.05^{c}$ & $5.24^{c}$ & $5.77^{b}$ & $5.97^{b}$ & $6.56^{\mathrm{a}}$ & 0.15 & $<0.01$ & $<0.01$ & 0.06 \\
\hline
\end{tabular}

Values are least square means ( $n=6$ per treatment), and zinc ( $\mathrm{Zn}$ ) concentration in the basal diet (no TBZC supplementation) was $125 \mathrm{mg} / \mathrm{kg}$ as $\mathrm{ZnSO}_{4}$. TBZC, tetrabasic zinc chloride; SEM, standard error of the mean.

1),2) Linear and quadratic effects of increasing TBZC concentrations (0 to 3,000 mg/kg Zn).

a-c Least square means within a row with different superscripts differ $(p<0.05)$.

Table 8. Effects of dietary tetrabasic zinc chloride supplementation on organ Zn concentrations in weaned pigs in Exp. 1

\begin{tabular}{|c|c|c|c|c|c|c|c|c|c|}
\hline \multirow{2}{*}{ Items } & \multicolumn{5}{|c|}{ TBZC (mg/kg Zn) } & \multirow{2}{*}{ SEM } & \multicolumn{3}{|c|}{$\mathrm{p}$-value } \\
\hline & 0 & 1,200 & 1,800 & 2,400 & 3,000 & & Treatment & Linear $^{1)}$ & Quadratic ${ }^{2)}$ \\
\hline Heart (mg/kg) & $24.27^{c}$ & $56.90^{c}$ & $92.22^{\mathrm{bc}}$ & $149.16^{\mathrm{ab}}$ & $199.85^{\mathrm{a}}$ & 23.20 & $<0.01$ & $<0.01$ & 0.14 \\
\hline Liver (mg/kg) & $106.60^{d}$ & $245.29^{c}$ & $644.28^{b}$ & $736.66^{b}$ & $987.32^{\mathrm{a}}$ & 43.96 & $<0.01$ & $<0.01$ & 0.03 \\
\hline Kindey (mg/kg) & $22.64^{c}$ & $26.85^{c}$ & $49.44^{c}$ & $135.02^{b}$ & $240.40^{\mathrm{a}}$ & 8.00 & $<0.01$ & $<0.01$ & 0.12 \\
\hline Pancreas $(\mathrm{mg} / \mathrm{kg})$ & $43.43^{c}$ & $91.92^{c}$ & $469.60^{b}$ & $363.74^{b c}$ & $937.69^{a}$ & 96.97 & $<0.01$ & $<0.01$ & 0.02 \\
\hline
\end{tabular}

Values are least square means ( $n=6$ per treatment), and zinc ( $\mathrm{Zn}$ ) concentration in the basal diet (no TBZC supplementation) was $125 \mathrm{mg} / \mathrm{kg}$ as $\mathrm{ZnSO}_{4}$.

TBZC, tetrabasic zinc chloride; SEM, standard error of the mean.

1),2) Linear and quadratic effects of increasing TBZC concentrations (0 to 3,000 mg/kg Zn).

a-d Least square means within a row with different superscripts differ $(p<0.05)$.

space in treatments with 2,400 and $3,000 \mathrm{mg} / \mathrm{kg} \mathrm{Zn}$ as TBZC (D4 and D5). In kidney, glomerular atrophy and renal tubular interstitial hyperemia were found (E5).

Growth performance and diarrhea incidence in Exp. 2 In phase 1 ( $\mathrm{d} 0$ to 14 ) and during the overall $28-\mathrm{d}$ period, pigs fed 2,250 $\mathrm{mg} / \mathrm{kg} \mathrm{Zn}$ as $\mathrm{ZnO}$ had greater ADG $(\mathrm{p}<0.05)$ than pigs fed the NC diet, but lower G:F $(p<0.05)$ than pigs receiving $\mathrm{Zn}$ from TBZC, regardless of TBZC supplemented concentrations (Table 9). In phase 2 (d 14 to 28), pigs fed 2,250 $\mathrm{mg} / \mathrm{kg} \mathrm{Zn}$ as $\mathrm{ZnO}$ showed greater $\mathrm{G}: \mathrm{F}(\mathrm{p}<0.05)$ than pigs fed the NC diet, but lower ADG $(\mathrm{p}<0.05)$ compared with pigs fed the TBZC supplemented diets.

During each phase in Exp. 2, ADG and G:F responded linearly $(\mathrm{p}<0.01)$ as the dietary supplemental TBZC concentration increased (Table 9). Weaned pigs fed 2,250 $\mathrm{mg} / \mathrm{kg} \mathrm{Zn}$ as $\mathrm{ZnO}$ had lower $(\mathrm{p}<0.01)$ diarrhea incidence than pigs fed the NC diet and showed similar diarrhea-reducing effect compared with pigs fed the TBZC supplemented diets.
Mineral absorption and excretion in Exp. 2

The percentages of $\mathrm{Zn}$ and $\mathrm{Cu}$ absorption responded quadratically $(\mathrm{p}<0.01)$ with increased dietary TBZC concentrations, and there was a quadratically response tendency $(\mathrm{p}=0.06)$ for the percentages of Fe absorption (Table 10). Weaned pigs fed $1,000 \mathrm{mg} / \mathrm{kg} \mathrm{Zn}$ as TBZC had lower $(\mathrm{p}<0.01)$ fecal $\mathrm{Zn}$ and greater $(\mathrm{p}=0.02) \mathrm{Cu}$ absorption than pigs fed the $\mathrm{ZnO}$ diet. The percentages of $\mathrm{Zn}, \mathrm{Cu}$, and Fe absorption in pigs fed diets containing $1,250 \mathrm{mg} / \mathrm{kg} \mathrm{Zn}$ as TBZC were greater than those of pigs fed the $\mathrm{ZnO}$ diet $(\mathrm{p}<0.01)$. However, pigs fed $1,500 \mathrm{mg} / \mathrm{kg} \mathrm{Zn}$ as TBZC showed negative $\mathrm{Zn}$ absorption on $\mathrm{d} 28$.

\section{DISCUSSION}

Previous studies have shown that the growth performance of weaned pigs quadratically enhanced as the dietary supplemental TBZC concentration increased [6,7]. Similarly, our study (Exp. 1) also showed that the growth performance quadratically changed as TBZC supplementation concentration 


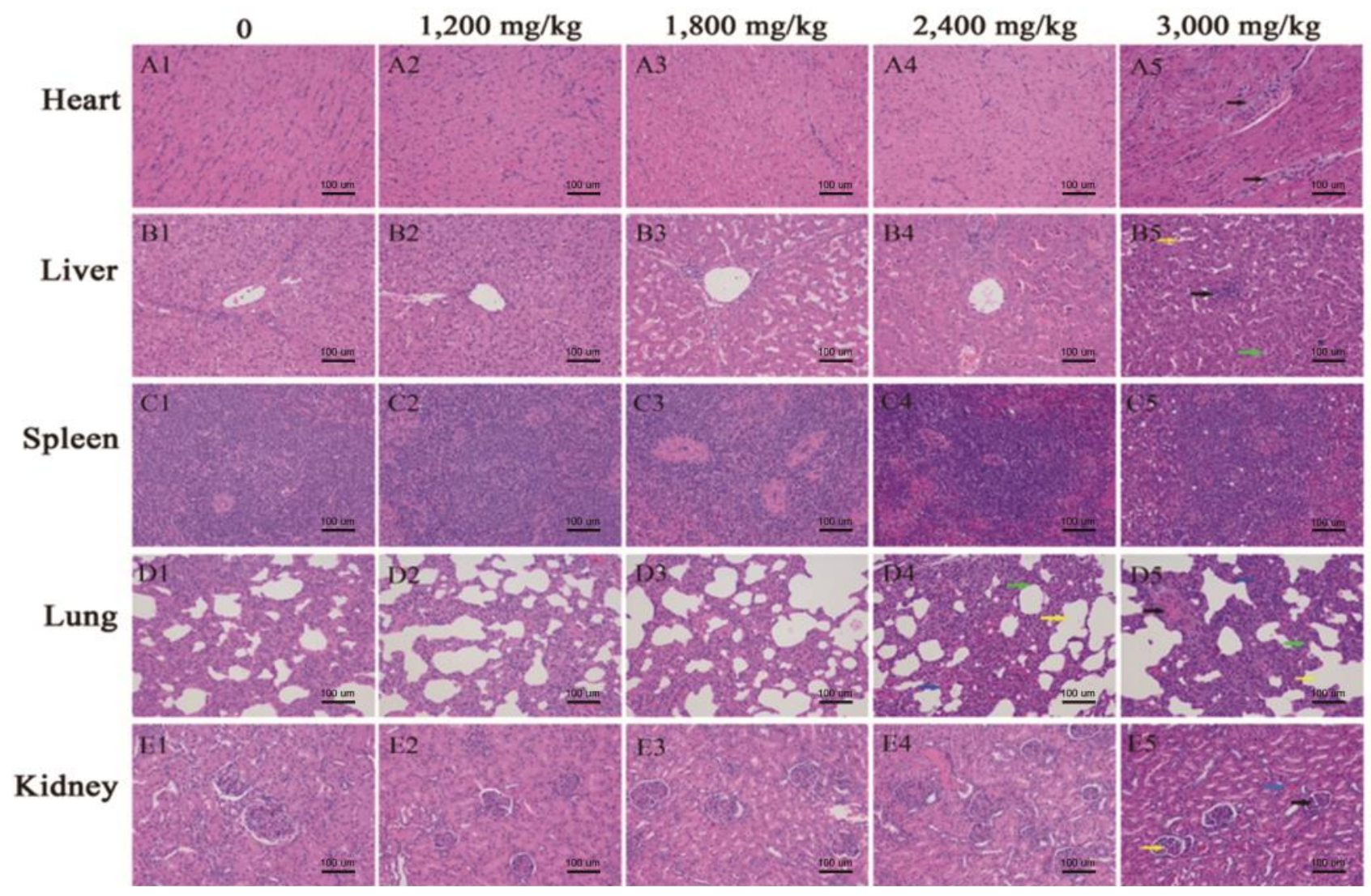

Figure 1. Effects of different concentrations ( 0 to $3,000 \mathrm{mg} / \mathrm{kg}$ zinc) of dietary tetrabasic zinc chloride (TBZC) supplementation on tissue structure of heart, liver, spleen, lung and kidney in weaned pigs. A-E represent tissues of heart, liver, spleen, lung and kidney, and 1-5 represent dietary TBZC supplemental concentrations of 0, 1,200, 1,800, 2,400, and 3,000 mg/kg zinc (Zn), respectively. Heart tissue with 3,000 mg/kg Zn as TBZC (A5) showed interstitial edema (black arrows); liver tissue with 3,000 mg/ $\mathrm{kg}$ Zn as TBZC (B5) showed stem cell swelling (green arrow), hepatic sinus dilatation (yellow arrow) and lymph cell infiltration (black arrow); lung tissue with 2,400 and $3,000 \mathrm{mg} / \mathrm{kg}$ Zn as TBZC (D4 and D5, respectively) exhibited alveolar collapse and compensatory expansion of the alveolar spaces (yellow arrows), thickened alveolar wall (green arrows), and proteinaceous mucus in the alveolar space (blue arrows and black arrow); kidney tissue with 3,000 mg/kg Zn as TBZC (E5) exhibited glomerular lobes (yellow arrow), atrophy (black arrow), and tubulointerstitial hyperemia (blue arrow). H\&E, $\times 200$.

increased from 0 to $3,000 \mathrm{mg} / \mathrm{kg}$ for the overall 28 -d period. However, in phase 2 and overall period, the growth performance of weaned pigs decreased to the same level as the control group when TBZC was supplemented at $3,000 \mathrm{mg} / \mathrm{kg}$, which is consistent with previous reports that pigs fed 3,000 $\mathrm{mg} / \mathrm{kg} \mathrm{Zn}$ had similar or slightly increased growth performance compared to the Zn-deficient treatment [3,6,12]. Growth retardation under excessive ingestion of $\mathrm{Zn}$ were also observed in rats and hens $[13,14]$. These results indicated that long-term intake of high-Zn diets may have potentially negative effects on growth and G:F in animals such as weaned pigs. The impaired growth performance was most likely due to a marginal $\mathrm{Zn}$ toxicity as $\mathrm{Zn}$ accumulates in tissues. Moreover, $1,800 \mathrm{mg} / \mathrm{kg} \mathrm{Zn}$ as TBZC supplementation resulted in the best growth performance in phase 2 and the overall period, while $1,200 \mathrm{mg} / \mathrm{kg} \mathrm{Zn}$ as TBZC led to the best growth performance in phase 1. Mavromichalis et al [7] reported that concentrations of supplemental TBZC greater than 1,500 $\mathrm{mg} / \mathrm{kg}$ were no more efficacious on growth performance than the $1,500 \mathrm{mg} / \mathrm{kg} \mathrm{Zn}$ dose concentration on nursery pigs in a 21-d assay, which exactly falls into our optimal concentration range $(1,200$ to $1,800 \mathrm{mg} / \mathrm{kg} \mathrm{Zn})$ of dietary TBZC supplementation in weaned pigs from Exp. 1.

In practice, pharmacological dose of $\mathrm{Zn}$ is widely supplemented in weaned pig diets to enhance the growth performance and, more importantly, to reduce the incidence of post-weaning diarrhea, which has been widely reported $[6,15]$. In our study, pigs fed diets supplemented with TBZC showed significantly lower diarrhea incidence than those fed the basal diet, indicating that TBZC is an effective $\mathrm{Zn}$ source in diarrhea alleviation, which is consistent with another study focusing on dietary TBZC supplementation and fecal scores [6]. However, the mechanisms of the anti-diarrhea effect by $\mathrm{Zn}$ are still not fully elucidated. It had been suggested that this effect of $\mathrm{Zn}$ could be attributed to its function in inhibiting pathogenic bacterial adhesion, preserving intestinal epithelial barrier integrity, and enhancing mucosal restorability [16]. Zhang and Guo [1] reported that dietary $\mathrm{Zn}$ supplementation at 2,000 $\mathrm{mg} / \mathrm{kg}$ led to a marked decline in fecal scores caused by reduced intestinal permeability. Katouli et al [17] pointed out 
Table 9. Effects of dietary tetrabasic zinc chloride supplementation on growth performance and diarrhea incidence of weaned pigs in Exp. 2

\begin{tabular}{|c|c|c|c|c|c|c|c|c|c|c|}
\hline \multirow{3}{*}{ Items } & \multirow{2}{*}{\multicolumn{4}{|c|}{ TBZC (mg/kg Zn) }} & \multirow{3}{*}{$\frac{\mathrm{ZnO}(\mathrm{mg} / \mathrm{kg} \mathrm{Zn})}{2,250}$} & \multirow{3}{*}{ SEM } & \multicolumn{4}{|c|}{$p$-value ${ }^{1)}$} \\
\hline & & & & & & & \multirow{2}{*}{$\mathrm{NC}$ vs $\mathrm{ZnO}$} & \multirow{2}{*}{ TBZC vs Zno } & \multicolumn{2}{|c|}{ TBZC } \\
\hline & 0 (NC) & 1,000 & 1,250 & 1,500 & & & & & Linear & Quadratic \\
\hline \multicolumn{11}{|l|}{ Phase $1, \mathrm{~d} 0$ to 14} \\
\hline ADG $(g)$ & 326 & 356 & 378 & 370 & 356 & 8.28 & 0.02 & 0.04 & $<0.01$ & 0.72 \\
\hline ADFI (g) & 513 & 548 & 557 & 551 & 553 & 13.82 & 0.03 & 0.89 & 0.14 & 0.54 \\
\hline $\mathrm{G}: \mathrm{F}$ & 0.63 & 0.65 & 0.68 & 0.67 & 0.64 & 0.01 & 0.28 & 0.02 & $<0.01$ & 0.57 \\
\hline Diarrhea incidence (\%) & 17.76 & 7.47 & 4.78 & 3.75 & 5.06 & 0.88 & $<0.01$ & 0.78 & $<0.01$ & $<0.01$ \\
\hline \multicolumn{11}{|l|}{ Phase 2, d 14 to 28} \\
\hline $\mathrm{ADG}(\mathrm{g})$ & 469 & 517 & 529 & 540 & 502 & 12.66 & 0.08 & 0.02 & $<0.01$ & 0.98 \\
\hline ADFI (g) & 883 & 922 & 907 & 929 & 892 & 22.78 & 0.74 & 0.16 & 0.22 & 0.90 \\
\hline $\mathrm{G}: \mathrm{F}$ & 0.53 & 0.56 & 0.58 & 0.58 & 0.56 & 0.01 & 0.04 & 0.07 & $<0.01$ & 0.96 \\
\hline Diarrhea incidence (\%) & 9.59 & 3.75 & 2.73 & 2.53 & 3.60 & 0.56 & $<0.01$ & 0.43 & $<0.01$ & 0.06 \\
\hline \multicolumn{11}{|l|}{ Overall, d 0 to 28} \\
\hline ADG (g) & 397 & 437 & 454 & 455 & 429 & 8.41 & 0.02 & 0.01 & $<0.01$ & 0.84 \\
\hline ADFI (g) & 698 & 735 & 732 & 740 & 723 & 15.19 & 0.19 & 0.33 & 0.07 & 0.71 \\
\hline $\mathrm{G}: \mathrm{F}$ & 0.58 & 0.60 & 0.63 & 0.62 & 0.60 & 0.01 & 0.07 & 0.02 & $<0.01$ & 0.68 \\
\hline Diarrhea incidence (\%) & 13.67 & 5.61 & 3.76 & 3.14 & 4.33 & 0.53 & $<0.01$ & 0.73 & $<0.01$ & $<0.01$ \\
\hline
\end{tabular}

Values are least square means ( $n=8$ per treatment).

TBZC, tetrabasic zinc chloride; NC, negative control without zinc (Zn) source supplementation; ZnO, positive control, NC+2,250 mg/kg Zn as Zn oxide (ZnO); SEM, standard error of the mean; $A D G$, average daily gain; $A D F I$, average daily feed intake; G:F, feed efficiency.

1) Comparisons between the NC diet vs the ZnO diet, and the ZnO diet vs mean of TBZC treatments (1,000 to 1,500 mg/kg Zn) using contrast. Linear and quadratic effects of increasing TBZC concentrations (0 to 1,500 mg/kg Zn).

that $\mathrm{Zn}$ included in the weaned pig diets could maintain the stability of intestinal microecology, and thereby reduce diarrhea occurrence caused by the excessive proliferation of pathogenic Escherichia coli (E. coli). Similarly, sequencing studies in pigs have shown that high dietary $\mathrm{Zn}$ supplementation increased intestinal microflora diversity and reduced the occurrence of pathogenic E. coli strains [18]. Therefore, an improved gut health through Zn supplementation may explain the alleviated diarrhea. The reduction in chloride secretion and subsequent reduction of water secretion into the intestinal may also con-

Table 10. Effects of dietary tetrabasic zinc chloride supplementation on mineral absorption and excretion in weaned pigs in Exp. 2

\begin{tabular}{|c|c|c|c|c|c|c|c|c|c|c|c|}
\hline \multirow{3}{*}{ Items } & \multirow{2}{*}{\multicolumn{4}{|c|}{ TBZC (mg/kg Zn) }} & \multirow{3}{*}{$\begin{array}{c}\begin{array}{c}\mathrm{ZnO} \\
(\mathrm{mg} / \mathrm{kg} \mathrm{Zn})\end{array} \\
2,250\end{array}$} & \multirow{3}{*}{ SEM } & \multicolumn{5}{|c|}{ p-value ${ }^{1)}$} \\
\hline & & & & & & & \multirow{2}{*}{$\begin{array}{l}\text { TBZC }_{1000} \\
\text { vs ZnO }\end{array}$} & \multirow{2}{*}{$\begin{array}{l}\text { TBZC }_{1250} \\
\text { vs ZnO }\end{array}$} & \multirow{2}{*}{$\begin{array}{l}\text { TBZC }_{1500} \\
\text { vs ZnO }\end{array}$} & \multicolumn{2}{|c|}{ TBZC } \\
\hline & 0 (NC) & 1,000 & 1,250 & 1,500 & & & & & & Linear & Quadratic \\
\hline Intake (mg/d) & 28 & 1,066 & 1,295 & 1,581 & 2,087 & 67.00 & $<0.01$ & $<0.01$ & 0.02 & $<0.01$ & 0.49 \\
\hline Fecal (mg/d) & 44 & 897 & 941 & 1,618 & 1,788 & 61.45 & $<0.01$ & $<0.01$ & 0.17 & $<0.01$ & $<0.01$ \\
\hline \multicolumn{12}{|l|}{$\mathrm{Cu}$} \\
\hline Intake (mg/d) & 168 & 185 & 169 & 181 & 167 & 7.79 & 0.11 & 0.87 & 0.28 & 0.46 & 0.69 \\
\hline Fecal (mg/d) & 147 & 157 & 132 & 158 & 152 & 7.05 & 0.66 & 0.07 & 0.59 & 0.62 & 0.41 \\
\hline Absorption (\%) & 12.41 & 15.15 & 21.91 & 12.09 & 8.73 & 1.55 & 0.02 & $<0.01$ & 0.11 & 0.10 & 0.01 \\
\hline \multicolumn{12}{|l|}{$\mathrm{Fe}$} \\
\hline
\end{tabular}

Values are least square means ( $n=8$ per treatment).

TBZC, tetrabasic zinc chloride; NC, negative control without zinc (Zn) source supplementation; ZnO, positive control, NC+2,250 mg/kg Zn as Zn oxide (ZnO); SEM, standard error of the mean; $\mathrm{ADFl}$, average daily feed intake; $\mathrm{Cu}$, copper; Fe, iron.

1) Comparisons between the $\mathrm{TBZC}_{1000}$ diet vs the $\mathrm{ZnO}$ diet, the TBZC $\mathrm{T}_{1250}$ diet vs the $\mathrm{ZnO}$ diet, and the $\mathrm{TBZC}_{1500}$ diet vs the $\mathrm{ZnO}$ diet using contrast. Linear and quadratic effects of increasing TBZC concentrations (0 to 1,500 mg/kg Zn). 
tribute to diarrhea reduction [19]. Recent studies have reported a beneficial effect of nano-size $\mathrm{Zn}$ or organic $\mathrm{Zn}$ supplementation on immune response [5], during which process $\mathrm{Zn}$ could play a role through more complex mechanisms. Generally, weaned pigs with diarrhea are often accompanied by lower growth rate and feed utilization. Therefore, dietary $\mathrm{Zn}$ supplementation reduced the diarrhea incidence, and also could lead to the improved growth performance. Our data demonstrated that TBZC as a Zn source has a strong anti-diarrhea effect even at the dose of $1,200 \mathrm{mg} / \mathrm{kg} \mathrm{Zn}$, indicating that TBZC has a potential to replace $\mathrm{ZnO}$ as an anti-diarrhea agent.

Hematological traits are important parameters in evaluating health and immunity status of individual animal. In our study, the RBC count, HGB concentrations and HCT increased as the incremental concentrations of dietary TBZC supplementation, which may support the previous findings that $\mathrm{Zn}$ has a crucial effect on DNA synthesis, cell division and protein synthesis [20]. Study on rats supplied with low-zinc diet showed a significant reduction in RBC count, indicating that $\mathrm{Zn}$ is involved in erythrocyte formation and maturation [21]. Yanagisawa et al [13] reported that serum erythropoietin, the essential growth factor for erythroid lineage cell proliferation and differentiation, was profoundly increased in high-Zn diet group. Therefore, $\mathrm{Zn}$ may increase the RBC count by up-regulating the serum erythropoietin. Our results further confirmed the previous report that dietary $\mathrm{Zn}$ is involved in an increased HGB content and HCT in pigs [22], and these increases are obviously caused by the elevated RBC count. No effects of $\mathrm{Zn}$ sources supplementation on WBC and PLT levels were observed, which is consistent with previous studies [15,22].

Increased ALT and AST concentrations in serum are commonly used as diagnostic indicators for liver damage and dysfunction. Serumal ALP is a sensitive biomarker of hepatocyte necrosis by biliary obstruction. As shown in our study, AST and ALT levels in serum increased sharply when pigs were fed diets containing more than $2,400 \mathrm{mg} / \mathrm{kg} \mathrm{Zn}$ as TBZC, and similar changes of transaminases were also observed in rats [11]. Moreover, the ALP activity elevated linearly with the gradual increased supplemental concentrations of $\mathrm{Zn}$ sulfate or organic $\mathrm{Zn}$ in previous studies [23,24], which is in accordance with our results. The high serumal ALP activity together with the transaminases indicates a possible damage in liver in pigs with high concentrations of TBZC intake.

Zinc plays an important role in maintaining the antioxidant enzyme activities in tissues, protecting the cells against oxidative stress, and scavenging the free radicals $[20,25,26]$. The Zn-related antioxidant enzymes, including GSH-Px and SOD, could limit the effects of reactive oxygen species on tissues and are active in defense against oxidative cell damage [25]. In our study, 1,200 or $1,800 \mathrm{mg} / \mathrm{kg} \mathrm{Zn}$ as TBZC supplementation in diets increased the activities of GSH-PX and T-
AOC in liver, which is in accordance with other reports that dietary supplementation with appropriate concentrations of $\mathrm{Zn}$ could improve liver antioxidant capacity and help maintain liver health $[14,26]$. Moreover, it was revealed in our study that the activities of these antioxidant enzymes would decrease when supplementation concentration of dietary TBZC exceeded $1,800 \mathrm{mg} / \mathrm{kg} \mathrm{Zn}$. On the other hand, the MDA content showed opposite change with the aforementioned antioxidant enzyme activities. The MDA is a critical indicator for lipid peroxidation and oxidative damage caused by reactive oxygen species, which would influence cell membrane fluidity as well as the integrity of biomolecules $[25,26]$. Increased MDA content caused by high dietary $\mathrm{Zn}$ concentration is reported to be associated with lower antioxidant enzyme activities, and also associated with the oxidative cell damage in liver, which would allow ALT and AST to permeate into blood due to increased cell membrane permeability [25]. Therefore, the increased MDA level is in agreement with the increased transaminase levels in serum in our study. In general, the above results demonstrated that an appropriate concentration of dietary TBZC supplementation could enhance the hepatic antioxidant capacity in weaned pigs, while high TBZC concentration such as 2,400 mg/kg Zn may result in oxidative damage in liver, thus may negatively affect the growth performance of pigs.

Analysis of organ weight is a vital endpoint for identification of potentially harmful effects of experimental additives in animals. The linear increase in liver and kidney weights in our study further confirmed the previous results that high dietary $\mathrm{Zn}$ concentration led to the enlargement of liver and kidney weights $[20,27]$. The enlargement of organ weights is associated with the toxicity generated from excess $\mathrm{Zn}$ accumulation in tissues [28], which has been proved by our observations that feeding 3,000 $\mathrm{mg} / \mathrm{kg}$ supplemental $\mathrm{Zn}$ as TBZC resulted in a 9.3- and 10.6-fold increases in amount of $\mathrm{Zn}$ accumulation in liver (106.6 vs $987.3 \mathrm{mg} / \mathrm{kg}$ ) and kidney (22.6 vs $240.4 \mathrm{mg} / \mathrm{kg}$ ), respectively, compared with pigs fed the basal diet. Furthermore, increased synthesis of the $\mathrm{Zn}$ storage protein metallothionein and the oxidative stressrelated proteins under high $\mathrm{Zn}$ supplying may also contribute to the heavier liver weight $[27,28]$. It has been reported that increased kidney weight may be related to edema, and one possible pathogenesis of renal lesions could be increased concentration of the supplemented test substance (or its metabolite) as a function of the renal osmotic concentration gradients [29], which is consistent with the severe injury in the morphology of kidney in our study. However, the weight and index of lung decreased when TBZC supplementation increased from 1,800 mg/kg Zn to 2,400 mg/kg Zn, indicating that lung may be more sensitive to the excess $\mathrm{Zn}$ concentration. Further studies are necessary to elucidate the mechanisms of organ damage with high-dose of $\mathrm{Zn}$ supplementation. 
In the present study, the morphology of organs was evaluated based on histopathological observations. Zinc accumulation in heart, liver, lung and kidney resulted in mild or moderate structural changes to the aforementioned organs, and the damage of organs occurred when pigs were fed more than 2,400 $\mathrm{mg} / \mathrm{kg} \mathrm{Zn}$ as TBZC, which is in accordance with the results from the hematological and serum biomarkers analysis. Additionally, other researchers have observed similar or more pronounced changes in the hepatic and splenic tissues under high concentrations of $\mathrm{Zn}[11,13]$.

Based on the results of Exp. 1, we can conclude that dietary TBZC supplementation at 1,200 to $1,800 \mathrm{mg} / \mathrm{kg} \mathrm{Zn}$ resulted in the best growth performance and health status in weaned pigs. However, weaned pigs fed $1,800 \mathrm{mg} / \mathrm{kg} \mathrm{Zn}$ as TBZC showed a negative $\mathrm{Zn}$ balance, with $\mathrm{Zn}$ excreting in feces exceeding $\mathrm{Zn}$ consumed on a daily basis (data not shown). Hence, Exp. 2 was conducted with three concentrations of TBZC near $1,200 \mathrm{mg} / \mathrm{kg} \mathrm{Zn}$ addition to determine the optimal TBZC supplemental concentration in weaned pigs to minimize the fecal $\mathrm{Zn}$ excretion, and $\mathrm{ZnO}$ was a positive control in this experiment.

Our results in Exp. 2 further confirmed that feeding pharmacological concentrations of $\mathrm{ZnO}$ could increase growth performance and reduce diarrhea incidence in weaned pigs. Furthermore, compared to dietary supplementation with 2,250 $\mathrm{mg} / \mathrm{kg} \mathrm{Zn}$ as $\mathrm{ZnO}$, TBZC showed a strong growth-promoting effect and a similar anti-diarrhea effect at lower doses, suggesting that TBZC may have higher bioavailability than $\mathrm{ZnO}$. Mavromichalis et al [7] reported that the bioavailability of $\mathrm{Zn}$ in TBZC was two times more than that in $\mathrm{ZnO}$. Zhang and Guo [6] reported that the bioavailability of Zn in TBZC was $122.1 \%$ to $159.3 \%$ relative to that in $\mathrm{ZnO}$ based on different response characteristics. This may be attributed to the ionic form of $\mathrm{Zn}$ in TBZC being more easily absorbed in intestine than the $\mathrm{Zn}$ in the covalent bond form in $\mathrm{ZnO}$, since $\mathrm{Zn}$ is transported through the enterocytes by specific $\mathrm{Zn}$ transporters in the ionic form. Moreover, the high bioavailability of $\mathrm{Zn}$ could greatly help to decrease the $\mathrm{Zn}$ excretion.

In Exp. 2, after 28-d trial, weaned pigs fed the NC diet were in a negative $\mathrm{Zn}$ balance, indicating that part of the endogenous $\mathrm{Zn}$ is lost from the intestine. Endogenous $\mathrm{Zn}$ excretion is an unavoidable and constant metabolic loss, mainly being excreted by the secretion of pancreatic juice and intestinal exfoliated cells [30]. The $\mathrm{Zn}$ absorption in percentage was greater in pigs fed 1,000 or $1,250 \mathrm{mg} / \mathrm{kg} \mathrm{Zn}$ as TBZC than those fed 2,250 $\mathrm{mg} / \mathrm{kg} \mathrm{Zn}$ as $\mathrm{ZnO}$, which further demonstrated that dietary TBZC supplementation as a $\mathrm{Zn}$ source could reduce $\mathrm{Zn}$ excretion. When pigs were fed $1,500 \mathrm{mg} / \mathrm{kg} \mathrm{Zn}$ as TBZC the quantity of $\mathrm{Zn}$ in feces was approximately equal to the sum of dietary $\mathrm{Zn}$ intake and endogenous $\mathrm{Zn}$ excretion, and the $\mathrm{Zn}$ absorption seemed to reach a saturation point, indicating that this high concentration of TBZC was slightly excessive for weaned pigs. On the other hand, the results on the saturation point illustrated that pigs had absorbed excess $\mathrm{Zn}$ during $\mathrm{d} 26$ to 28 , which also proved that TBZC had greater bioavailability than $\mathrm{ZnO}$ during this period. Therefore, the optimal dose for dietary TBZC supplementation to reduce $\mathrm{Zn}$ excretion is 1,000 to $1,250 \mathrm{mg} \mathrm{Zn} / \mathrm{kg}$. Moreover, the percentages of $\mathrm{Cu}$ and $\mathrm{Fe}$ absorption rose before the supplemented TBZC concentration reached $1,250 \mathrm{mg} / \mathrm{kg} \mathrm{Zn}$. At lower dietary $\mathrm{Zn}$ concentrations, increased $\mathrm{Cu}$ and $\mathrm{Fe}$ absorption could be related to the $\mathrm{Zn}$ concentration which plays a role in the improved intestinal structure and growth performance [1]. Subsequently, reduction in $\mathrm{Cu}$ and $\mathrm{Fe}$ absorption after 1,250 $\mathrm{mg} / \mathrm{kg} \mathrm{Zn}$ as TBZC supplementation may be due to the antagonistic action of high $\mathrm{Zn}$ concentrations in the $\mathrm{Cu}$ and Fe absorption process, which has been reported by previous studies $[3,30]$.

\section{CONCLUSION}

Overall, our study demonstrated that dietary TBZC supplementation at 1,000 to $1,800 \mathrm{mg} / \mathrm{kg} \mathrm{Zn}$ improved growth performance, alleviated the diarrhea incidence and had no deleterious effect in weaned pigs. When dietary TBZC supplementation concentration was below $1,250 \mathrm{mg} / \mathrm{kg} \mathrm{Zn}$, the $\mathrm{Zn}$ excretion in manure could be significantly reduced compared to a pharmacological concentration of $\mathrm{ZnO}$. However, excessive (more than 2,400 $\mathrm{mg} / \mathrm{kg} \mathrm{Zn}$ ) dietary TBZC inclusion had adverse effects on organ tissue of weaned pigs. Therefore, TBZC could be a potential effective alternative to $\mathrm{ZnO}$ and the recommended supplemental concentration of TBZC in weaned pig diets is 1,000 to $1,250 \mathrm{mg} / \mathrm{kg} \mathrm{Zn}$.

\section{CONFLICT OF INTEREST}

We certify that there is no conflict of interest with any financial organization regarding the material discussed in the manuscript.

\section{ACKNOWLEDGMENTS}

This research was financially supported by the The National Key Research and Development Program of China (2017YFC 1600306). The authors would thank the faculty and staff in Ministry of Agriculture Feed Industry Centre for their support to this study. The authors declare that no competing interests on data, opinion and finance in this paper.

\section{REFERENCES}

1. Zhang BK, Guo YM. Supplemental zinc reduced intestinal permeability by enhancing occludin and zonula occludens protein-1 (ZO-1) expression in weaning piglets. Br J Nutr 
2009;102:687-93. https://doi.org/10.1017/S0007114509289033

2. Hill GM, Mahan DC, Carter SD, et al. Effect of pharmacological concentrations of zinc oxide with or without the inclusion of an antibacterial agent on nursery pig performance. J Anim Sci 2001;79:934-41. https://doi.org/10.2527/2001.794934x

3. Walk CL, Wilcock P, Magowan E. Evaluation of the effects of pharmacological zinc oxide and phosphorus source on weaned piglet growth performance, plasma minerals and mineral digestibility. Animal 2015;9:1145-52. https://doi.org/10.1017/ S175173111500035X

4. Zhang BK, Guo YM. The growth-promoting effect of tetrabasic zinc chloride is associated with elevated concentration of growth hormone and ghrelin. Asian-Australas J Anim Sci 2008;21:1473-8. https://doi.org/10.5713/ajas.2008.80057

5. Li MZ, Huang JT, Tsai YH, Mao SY, Fu CM, Lien TF. Nanosize of zinc oxide and the effects on zinc digestibility, growth performances, immune response and serum parameters of weanling piglets. Anim Sci J 2016;87:1379-85. https://doi.org/10. 1111/asj.12579

6. Zhang BK, Guo YM. Beneficial effects of tetrabasic zinc chloride for weanling piglets and the bioavailability of zinc in tetrabasic form relative to ZnO. Anim Feed Sci Technol 2007;135: 75-85. https://doi.org/10.1016/j.anifeedsci.2006.06.006

7. Mavromichalis I, Webel DM, Parr EN, Baker DH. Growthpromoting efficacy of pharmacological doses of tetrabasic zinc chloride in diets for nursery pigs. Can J Anim Sci 2001; 81:387-91. https://doi.org/10.4141/A01-005

8. Swinkels JW, Kornegay ET, Zhou W, et al. Effectiveness of a zinc amino acid chelate and zinc sulfate in restoring serum and soft tissue zinc concentrations when fed to zinc-depleted pigs. J Anim Sci 1996;74:2420-30. https://doi.org/10.2527/ 1996.74102420x

9. Pieper R, Martin L, Schunter N, et al. Impact of high dietary zinc on zinc accumulation, enzyme activity and proteomic profiles in the pancreas of piglets. J Trace Elem Med Biol 2015; 30:30-6. https://doi.org/10.1016/j.jtemb.2015.01.008

10.NRC. Nutrient requirements of swine. 11th ed. Washington, DC, USA: National Academy Press; 2012.

11. Kuang H, Yang P, Yang L, Aguilar ZP, Xu H. Size dependent effect of $\mathrm{ZnO}$ nanoparticles on endoplasmic reticulum stress signaling pathway in murine liver. J Hazard Mater 2016;317: 119-26. https://doi.org/10.1016/j.jhazmat.2016.05.063

12.Schell TC, Kornegay ET. Zinc concentration in tissues and performance of weanling pigs fed pharmacological levels of zinc from $\mathrm{ZnO}, \mathrm{Zn}-$ Methionine, Zn-Lysine, or ZnSO4. J Anim Sci 1996;74:1584-93. https://doi.org/10.2527/1996.7471584x

13. Yanagisawa H, Miyakoshi Y, Kobayashi K, et al. Long-term intake of a high zinc diet causes iron deficiency anemia accompanied by reticulocytosis and extra-medullary erythropoiesis. Toxicol Lett 2009;191:15-9. https://doi.org/10.1016/j.toxlet. 2009.07.024

14.El-Hack MEA, Alagawany M, Salah AS, et al. Effects of dietary supplementation of zinc oxide and zinc methionine on layer performance, egg quality, and blood serum indices. Biol Trace Elem Res 2018;184:456-62. https://doi.org/10.1007/s12011017-1190-0

15. Milani NC, Sbardella M, Ikeda NY, Arnoc A, Mascarenhas BC, Miyada VS. Dietary zinc oxide nanoparticles as growth promoter for weanling pigs. Anim Feed Sci Technol 2017;227: 13-23. https://doi.org/10.1016/j.anifeedsci.2017.03.001

16. Roselli M, Finamore A, Garaguso I, Britti MS, Mengheri E. Zinc oxide protects cultured enterocytes from the damage induced by Escherichia coli. J Nutr 2003;133:4077-82. https:// doi.org/10.1093/jn/133.12.4077

17.Katouli M, Melin L, Jensen-Waern M, Wallgren P, Möllby R. The effect of zinc oxide supplementation on the stability of the intestinal flora with special reference to composition of coliforms in weaned pigs. J Appl Microbiol 1999;87:564-73. https://doi.org/10.1046/j.1365-2672.1999.00853.x

18. Vahjen W, Pieper R, Zentek J. Increased dietary zinc oxide changes the bacterial core and enterobacterial composition in the ileum of piglets. J Anim Sci 2011;89:2430-9. https://doi. org/10.2527/jas.2010-3270

19. Medani M, Bzik VA, Rogers A, et al. Zinc sulphate attenuates chloride secretion in Human colonic mucosae in vitro. Eur J Pharmacol 2012;696:166-71. https://doi.org/10.1016/j.ejphar. 2012.09.017

20.Sun JY, Jing MY, Weng XY, et al. Effects of dietary zinc levels on the activities of enzymes, weights of organs, and the concentrations of zinc and copper in growing rats. Biol Trace Elem Res 2005;107:153-65. https://doi.org/10.1385/BTER:107:2:153

21.El Hendy HA, Yousef MI, Abo El-Naga NI. Effect of dietary zinc deficiency on hematological and biochemical parameters and concentrations of zinc, copper, and iron in growing rats. Toxicology 2001;167:163-70. https://doi.org/10.1016/S0300483X(01)00373-0

22. Trckova M, Lorencova A, Babak V, Neca J, Ciganek M. Effects of sodium humate and zinc oxide used in prophylaxis of post-weaning diarrhoea on the health, oxidative stress status and fatty acid profile in weaned piglets. Vet Med (Praha) 2017; 62:16-28. https://doi.org/10.17221/70/2016-VETMED

23. Revy PS, Jondreville C, Dourmad JY, Nys Y. Assessment of dietary zinc requirement of weaned piglets fed diets with or without microbial phytase. J Anim Physiol Anim Nutr 2006; 90:50-9. https://doi.org/10.1111/j.1439-0396.2005.00576.x

24. Nagalakshmi D, Sridhar K, Parashuramulu S. Replacement of inorganic zinc with lower levels of organic zinc (zinc nicotinate) on performance, hematological and serum biochemical constituents, antioxidants status, and immune responses in rats. Vet World 2015;8:1156-62. https://doi.org/10.14202/ vetworld.2015.1156-1162

25. Yin LL, Zhang Y, Guo DM, An K, Yin MS, Cui X. Effects of zinc on interleukins and antioxidant enzyme values in psoriasisinduced mice. Biol Trace Elem Res 2013;155:411-5. https:// 
doi.org/10.1007/s12011-013-9799-0

26.Zhao CY, Tan SX, Xiao XY, Qiu XS, Pan JQ, Tang ZX. Effects of dietary zinc oxide nanoparticles on growth performance and antioxidative status in broilers. Biol Trace Elem Res 2014; 160:361-7. https://doi.org/10.1007/s12011-014-0052-2

27.Park SY, Birkhold SG, Kubena LF, Nisbet DJ, Ricke SC. Effects of high zinc diets using zinc propionate on molt induction, organs, and postmolt egg production and quality in laying hens. Poult Sci 2004;83:24-33. https://doi.org/10.1093/ps/83. 1.24

28. Martin L, Pieper R, Schunter N, Vahjen W, Zentek J. Perfor- mance, organ zinc concentration, jejunal brush border membrane enzyme activities and mRNA expression in piglets fed with different levels of dietary zinc. Arch Anim Nutr 2013;67: 248-61. https://doi.org/10.1080/1745039X.2013.801138

29. Crowell JA, Korytko PJ, Morrissey RL, Booth TD, Levine BS. Resveratrol-associated renal toxicity. Toxicol Sci 2004;82:6149. https://doi.org/10.1093/toxsci/kfh263

30. Rincker MJ, Hill GM, Link JE, Meyer AM, Rowntree JE. Effects of dietary zinc and iron supplementation on mineral excretion, body composition, and mineral status of nursery pigs. J Anim Sci 2005;83:2762-74. https://doi.org/10.2527/2005.83122762x 